\title{
Pentingnya Penerapan Nilai-Nilai Pancasila Pada Remaja di Era Society 5.0
}

\author{
Delita Putri Bintari, Dewi Masyithoh*, Dwi Mulya Pratiwi \\ Psikologi, Universitas Jenderal Achmad Yani Yogyakarta, 55294, Yogyakarta, Indonesia
}

\begin{abstract}
Abstrak.
Di Era Society 5.0 erat kaitannya dengan kemajuan teknologi dan informasi yang sangat canggih dimana remaja pada masa ini juga merasakan dampaknya.Permasalahan yang dialami saat ini adalah memudarnya pemahaman tentang pancasila dikalangan remaja yang sangat berpotensi masuknya paham-paham yang bertentangan seperti muncul banyaknya kriminalitas, kolusi dan nepotisme, radikalisme, korupsi,kejahatan seksual, kehidupan yang konsumtif, kehidupan politik yang tidak produktif, dan lain sebagainya.Tentu itu akan menjadi ancaman bagi para generasi emas bangsa Indonesia. Remaja kini hanya sekedar hapal Pancasila saja namun tidak paham makna setiap nilai yang terkandung didalamnya.Bahkan saat ini jarang sekali yang mengamalkan dalam kehidupan sehari-hari.Melihat fakta yang terjadi dikalangan remaja saat ini, maka sudah seharusnya penanaman nilai Pancasila diterapkan sedini mungkin.Tujuan dari penelitian ini adalah untuk mengetahui pemahaman para remaja terhadap nilai-nilai pancasila beserta makna yang terkandung didalamnya dan mengetahui apakah nilai-nilai pancasila tersebut masih diterapkan dalam kehidupan bermasyarakat.Metode penelitan menggunakan pendekatan deskriptif kualitatif dengan teknik pengumpulan data dalam bentuk Google Form dimana tautannya ditujukan bagi remaja berusia 1218 tahun. Hasil penelitian menunjukkan bahwa pancasila merupakan landasan negara, pedoman hidup serta kepribadian negara Indonesia yang berisi nilai-nilai kehidupan bernegara dimana jika telah diterapkan dapat membentuk karakter diri seseorang menjadi lebih baik. Kesimpulan penelitian ini adalah Pancasila sangat berpengaruh dalam menentukan masa depan di era society 5.0 ini dan perlu diketahui juga jika penanaman nilai Pancasila itu sangat perlu ditanamkan sejak dini guna mencapai tujuan tersebut, saat ini masih banyak juga remaja yang hanya mengetahui pelafalannya saja tanpa tahu makna yang terkandung dan cara penerapannya.
\end{abstract}

Kata kunci.

Nilai-nilai Pancasila, Remaja, Era Society 5.0.

\section{PENDAHULUAN}

Pancasila merupakan kepribadian bangsa yang berisi nilai-nilai sebagai landasan budaya bangsa, nilai-nilai tersebut merupakan bentuk dari keinginan bangsa dan merupakan bentuk ideologi Indonesia. Pancasila kerap kali dikelompokkan ke dalam ideologi tengah karena sifatnya bukan termasuk kedua ideologi besar dunia yang paling berpengaruh (Wulandari \&

\section{* Corresponding author: dewimasyithoh730@gmail.com}

Received 1 November 2021; Received in revised form 10 November 2021; Accepted 11 November 2021 Available online 28 December 2021

Lembaga Penelitian dan Pengabdian Kepada Masyarakat

Universitas Lampung 
Dewi, 2021) [1]. Pendidikan yang didasarkan Pancasila serta undang undang Dasar 1945 yang berakar pada agama, budaya, nilai-nilai Pancasila, dan tanggap akan perubahan jaman dengan tujuan menambah kualitas manusia adalah Pendidikan Nasional [2]. Bangsa Indonesia telah menerima Pancasila sebagai landasan hidup berbangsa dan memiliki fungsi penting di negara Indonesia sebagai jati diri Indonesia, filsafat negara, dan asas persatuan Indonesia.

Pancasila merupakan sesuatu yang sakral dan warga negaranya harus mengerti makna Pancasila itu sendiri. Tetapi sebagian masyarakat Indonesia menganggap jika Pancasila hanya sebatas ideologi tanpa menyoroti makna yang ada dalam Pancasila tersebut. Tanpa disadari nilai dan makna Pancasila itu bermanfaat apabila diamalkan dengan baik. Permasalahan yang terjadi karena ketidak pahaman ketika memahami makna Pancasila serta mengamalkan Pancasila. Pancasila tidak hanya sekedar memahami tetapi bagaimana caranya mengamalkan dalam kehidupan [3].

Berkembangnya zaman juga beriringan dengan berkembangnya teknologi serta informasi sehingga modernitas tidak bisa lagi dihindari. Pada Era Society 5.0 ini, para remaja telah mengenal media social yang merupakan media atau tempat bagi para pengguna untuk bersosialisasi dan mendapatkan informasi terkini juga sebagai tempat pengekspresian diri dengan jangkauan yang tidak terbatas. Namun mirisnya remaja saat ini terdampak oleh arus globalisasi yang cenderung pada hal negatif. Mereka lebih banyak menerapkan budaya yang bertentangan dengan nilai-nilai Pancasila yang merupakan bagian dari kebudayaan Indonesia sehingga menyebabkan pemahaman akan nilai-nilai Pancasila dikalangan remaja saat ini menurun [4]. Remaja kini hanya sekedar hapal Pancasila saja namun tidak paham makna yang terkandung didalamnya. Jarang sekali yang mengamalkan dalam kehidupan sehari-hari dan lebih parahnya tidak peduli dengan aturan yang tertera di Pancasila.Sekarang Pancasila tidak lagi menjadi landasan dalam bertindak diberbagai aspek kehidupan. Melihat fakta yang terjadi dikalangan remaja saat ini, maka sudah seharusnya penanaman nilai Pancasila diterapkan sejak dini dan memberikan pemahaman kepada remaja bahwa Pancasila merupakan landasan bagi mereka untuk menemukan jati dirinya [5].

Permasalahan yang dialami Indonesia adalah memudarnya semangat nasionalisme pada anak remaja di era sekarang. Permasalahan tersebut tentu sangat dikhawatirkan karena nantinya remaja Indonesia tidak lagi menjunjung tinggi nilai-nilai Pancasila sebagai bentuk warga negara yang baik karena kehilangan terhadap jati diri bangsanya sendiri [6]. Hal tersebut terjadi karena adanya pengaruh budaya luar yang masuk ke Indonesia yang membuat para anak remaja lebih tertarik untuk mengikuti budaya asing daripada budaya negaranya sendiri.Situasi ini berdampak bagi generasi muda seperti melupakan budaya sendiri, memuji kebudayaan Barat, kurangnya memahami nilai-nilai pada budaya sendiri.Hal ini dikarenakan para generasi muda menganggap bahwa budaya luar sebagai budaya yang lebih keren dibanding budaya bangsa sendiri. Hal ini yang berakibat nilai-nilai luhur bangsa mulai tersingkirkan [3].

Pada era ini, diikuti oleh adanya trend yang semakin canggih dan modern yang diwarnai oleh ketidakteraturan dan ketidakpastian dapat menimbulkan kecenderungan pada permasalahan baru yang semakin beragam.Seperti munculnya berbagai dekadensi moral seperti banyaknya terjadi kasus kolusi dan nepotisme, kriminalitas, korupsi, radikalisme, kejahatan seksual, kehidupan yang konsumtif, kehidupan politik yang tidak produktif, dan lain-lain yang tiada hentinya menjadi topik fokus masyarakat saat ini.Sehingga peristiwa tersebut seolah-olah menjadi hal yang lumrah di dengar oleh masyarakat. Fenomena dekadensi moral ini dapat terjadi karena suatu bangsa yang kehilangan identitas dirinya. 
Mereka kurang mampu memilah dan memilih budaya asing yang masuk ke Indonesia. Sesungguhnya, bangsa ini memiliki ideologi Pancasila yang merupakan karakter bangsa yang kini dikalangan para remaja pemahamannya semakin mulai memudar. Padahal mulai dari sila pertama hingga ke lima, semuanya sudah mencakup berbagai lini kehidupan yang dijalani manusia [7]. Banyak dampak yang ditimbulkan dari perubahan yang disebabkan oleh adanya globalisasi antara lain mulai terkikisnya rasa nasionalisme dan telah muncul teknologi-teknologi canggih yang sangat membantu kebutuhan manusia tetapi dapat merusak moral dan mental generasi muda. Melihat dari polarisasi dikehidupan saat ini mulai melenceng dari norma dasar yang terkandung dalam nilai-nilai pancasila contohnya saja seperti kenakalan pada remaja.

Maka dari itu untuk mengurangi hal-hal negatif lainnya terjadi, membentuk karakter anak sejak dini itu sangat penting untuk perkembangannya di masa depan. Karakter tersebut perlu dipelajari melalui pendidikan karakter di awali dari pendidikan yang paling dasar sampai ke pendidikan tinggi yang khususnya kepada penerapan nilai pancasila pada remaja di kehidupan saat ini yang sedikit mengetahui pentingnya nilai Pancasila tersebut. Maka dari itu, inilah yang bisa kita lakukan guna dapat menanamkan nilai-nilai Pancasila antara lain selalu beribadah kepada Tuhan Yang Maha Esa, memahami seperti apa perasaan empati dan simpati, mempelajari tentang kebersamaan, menggunakan hak dan kewajiban dengan baik, dan membiasakan diri bersikap adil dalam segala hal. Selain itu, faktor dari lingkungan sosial juga merupakan faktor pendukung utama untuk mewujudkan remaja Indonesia yang bermutu pada Era Society 5.0 ini. Namun proses dari pendidikan yang memiliki mutu juga tidak hanya cukup untuk dilakukan melalui transformasi ilmu pengetahuan dan teknologi tetapi harus ada dukungan juga oleh meningkatnya profesionalisme dan system pada manajemen pendidikan serta berkembangnya kemampuan demi mencapai cita cita. Oleh karna itu kita harus mengenalkan apa itu pancasila dan apa saja nilai-nilai yang terkandung pada pancasila dan integrasinya pada kalangan remaja, kita harus masuk terlebih dahulu pada jiwa-jiwa remaja sehingga kita dapat lebih mudah untuk mengenalkan nilai-nilai Pancasila.

\section{METODE}

Pada penelitian ini, penulis menggunakan metode pendekatan deskriptif kualitatif dengan menggunakan teknik pengumpulan data kuesioner terbuka dalam bentuk google form. Pertanyaan yang diajukan bersifat terbuka yang berisi daftar pertanyaan yang sudah menyertai alternatif jawaban namun tetap disediakan juga ruang untuk menyampaikan alasan mengapa mereka menjawab demikian.

Dimulai nya penelitian ini pada tanggal 29 November 2021 dengan menyebarkan kuesioner kepada Remaja berusia 12-18 Tahun melalui grup WhatsApp. Sebelumnya, peneliti telah menjelaskan tujuan dilakukannya hal tersebut adalah untuk mengetahui sejauh mana para remaja memahami tentang pentingnya penerapan nilai-nilai Pancasila dalam kehidupan sehari-hari khususnya di Era Society 5.0 ini.

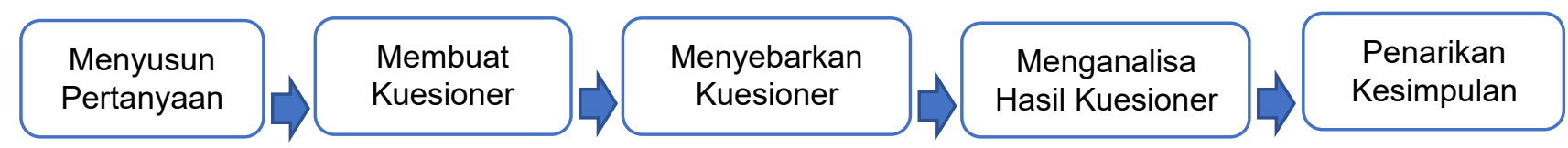

Gambar 1. Alur penelitian ini adalah sebagai berikut 


\section{HASIL DAN PEMBAHASAN}

Hasil dari penyebaran kuesioner yang dilakukan pada tanggal 29 November 2021 diperoleh informasi yang disajikan dalam bentuk tabel di bawah ini:

Tabel 1. Pemahaman remaja terhadap nilai dan makna Pancasila

\begin{tabular}{|c|c|c|c|}
\hline No & Pernyataan & Hasil & Keterangan \\
\hline 1 & $\begin{array}{l}\text { Pancasila penting untuk diterapkan } \\
\text { dalam kehidupan sehari-hari }\end{array}$ & $\begin{array}{l}55,6 \% \text { Responden } \\
\text { Sangat Setuju. }\end{array}$ & $\begin{array}{l}\text { Responden memberikan } \\
\text { pendapat bahwa Pancasila itu } \\
\text { merupakan dasar negara, } \\
\text { pedoman hidup, dan } \\
\text { kepribadian bangsa Indonesia } \\
\text { yang berisi nilai-nilai } \\
\text { kehidupan bernegara dimana } \\
\text { jika telah diterapkan dapat } \\
\text { membentuk karakter diri } \\
\text { seseorang menjadi lebih baik }\end{array}$ \\
\hline 2 & $\begin{array}{l}\text { Di Era Society } 5.0 \text {, nilai-nilai Pancasila } \\
\text { jarang sekali diterapkan }\end{array}$ & $\begin{array}{l}47,7 \% \text { Responden } \\
\text { Cukup Setuju }\end{array}$ & - \\
\hline 3 & $\begin{array}{l}\text { Pendidikan Pancasila perlu ditanamkan } \\
\text { sedini mungkin }\end{array}$ & $\begin{array}{l}66,7 \% \text { Responden } \\
\text { Sangat Setuju }\end{array}$ & - \\
\hline 4 & $\begin{array}{l}\text { Remaja mengetahui apa saja nilai-nilai } \\
\text { dan makna setiap nilai-nilai Pancasila }\end{array}$ & $\begin{array}{l}55,6 \% \text { Responden } \\
\text { Setuju }\end{array}$ & $\begin{array}{l}\text { Responden dapat } \\
\text { memberikan contoh meskipun } \\
\text { hanya satu atau dua nilai } \\
\text { serta mampu menjelaskan } \\
\text { makna dari nilai tersebut }\end{array}$ \\
\hline 5 & $\begin{array}{l}\text { Remaja sudah menerapkan nilai-nilai } \\
\text { Pancasila di dalam kehidupan sehari-hari }\end{array}$ & $\begin{array}{l}66,7 \% \text { Responden } \\
\text { Setuju }\end{array}$ & $\begin{array}{l}\text { Secara garis besar, } \\
\text { responden banyak yang telah } \\
\text { menerapkan nilai beribadah } \\
\text { kepada Tuhan Yang Maha } \\
\text { Esa, menghormati } \\
\text { peribadatan agama lain, dan } \\
\text { menghargai perbedaan dari } \\
\text { segi suku, budaya, dan lain } \\
\text { sebagainya }\end{array}$ \\
\hline
\end{tabular}

Berdasarkan hasil dari penelitian yang kami lakukan pada remaja berusa 12-18 tahun menunjukkan jika remaja menganggap keberadaan Pancasila dianggap penting untuk menjadi fondasi hidup negara dengan memiliki tujuan yang bisa dianggap bermanfaat untuk Indonesia. Nilai yang terkandung dalam Pancasila menjadi aspek penting untuk setiap warga negara dalam bertingkah laku. Dengan pengamalan nilai-nilai Pancasila, diharapkan warga Negara Indonesia dapat memahami apa yang menjadi kewajiban dan haknya mereka. Namun, sampai kini masih dipertanyakan apakah seluruh nilai Pancasila selalu berkesinambungan dengan kemampuan seseorang memahami hak serta kewajibannya. Sejauh ini, masih belum terdapat penelitian yang melihat hubungan antara kelima sila dalam Pancasila dan kewarganegaraan [8]. Remaja saat ini masih banyak yang belum mengamalkannya dalam kehidupan bahkan hanya sekedar mengetahui saja. Miris memang jika kita melihat, kini remaja yang harusnya menjadi generasi penerus yang nantinya akan memimpin bangsa ini tapi malah kurang pemahamannya tentang landasan negara ini, dalam penelitian ini juga remaja meyakni jika pancasila memang penting bagi generasi penerus apalagi dimasa era globalisasi yang sangat berkembang pesat ini [9].

Lingkungan sosial juga merupakan tinjauan sosiologis yang merupakan sorotan yang berdasarkan pada hubungan antara manusia, Lingkungan sosial tersebut akan membentuk pergaulan yang nantinya akan membentuk kepribadaian para remaja. Lingkungan sosial juga menjadikan penyebab yang mampu berpengaruh pada seseorang untuk melakukan suatu tindakan dan perubahan perilaku masing-masing individu [10].

Nilai- nilai yang tercantum pada Pancasila mempunyai serangkaian nilai-nilai yang diawali 
dengan ketuhanan lalu berikutnya kemanusiaan, persatuan, kerakyatan, serta keadilan. Kelima nilai tersebut mempunyai tujuan yang satu. Nilai- nilai bawah Pancasila mempunyai watak yang umum serta objektif yang maksudnya nilai tersebut bisa digunakan serta diakui oleh negeri lain walaupun nilai tersebut tidak diberi nama Pancasila. Pancasila yang mempunyai sifat subjektif yang artinya nilai- nilai Pancasila yang menempel pada pembawa serta pendukung nilai Pancasila, yakni pada warga, bangsa, serta negeri Indonesia. Nilainilai Pancasila juga ialah pemikiran dari hidupnya bangsa Indonesia. Salain itu pancasila serta berupa nilai- nilai yang sangat cocok dengan hati nurani bangsa Indonesia, karna nilai tersebut barasal dari karakter bangsa. Nilai- nilai Pancasila juga jadi landasan bawah, dan motivasi dari perbuatan baik yang ada kehidupan tiap hari. Dalam kenegaraan, nilai Pancasila wajib nampak dalam peraturan perundangan yang berlaku di Indonesia. Sebab terlihatnya nilai-nilai Pancasila didalam aturan-aturan bisa memusatkan segala warga buat berlagak cocok dengan perundangan yang sudah disesuaikan dengan nilai-nilai Pancasila [3].

Anak muda ialah bagian berarti dalam keberlangsungan suatu negeri, yang didalam implementasinya anak muda ialah sumber energi manusia selaku pembangunan bangsa, penerus generasi dan jadi penentu masa depan. Tidak hanya memegang peranan berarti untuk bangsa serta negeri, anak muda wajib dicermati berkembang kembangnya supaya anak bisa berkembang jadi generasi yang memiliki jiwa pemimpin serta nyatanya bermutu. Kedudukan orangtua serta area dekat ialah peranan berarti yang hendak membentuk kepribadian anak muda. Banyak anak muda yang melaksanakan kejahatan serta kenakalan anak muda yang minimnya bimbingan serta penanaman nilai pancasila pada dirinya pula diiringi dengan pengaruh area sosialnya. Anak muda dikala ini memanglah terus menjadi jauh dari nilai nilai pancasila. Sebab itu butuh dikerjakannya sosialiasasi selaku upaya penanaman kembali kepribadian anak muda cocok dengan nilai- nilai Pancasila. Tujuan dikerjakannya sosialisasi pada anak muda merupakan selaku refleksi dalam membangun kembali kepribadian anak muda supaya nantinya bersamaan tumbuh nya teknologi nilai nilai pancasila senantiasa tertanam dalam diri anak muda [11].

Generasi muda pada dikala ini sepatutnya telah menyadari kalau mereka saat ini merupakan harapan bangsa yang diandalkan buat membangun keterbelakangan. Selaku generasi penerus bangsa anak muda dikala ini harus mempunyai kedudukan serta posisi yang strategis sebab mereka yang akan menentukan maju mundurnya alur di sesuatu bangsa. Kita selaku generasi penerus wajib dapat melaksanakan tugas serta kewajiban kita, ialah sanggup melaksanakan suatu pergantian. Kita selaku warga mempunyai kedudukan berarti dalam keadaan ini ialah kita wajib ikut serta langsung dalam upaya membetulkan bangsa kita. Tidak hanya itu, kita butuh wajib belajar jadi generasi yang mandiri biar kita dapat menyelamatkan bangsa kita dari keterpurukan [12].

Dengan semakin pesatnya pertumbuhan dalam ilmu pengetahuan serta teknologi yang terdapat di Indonesia, menjadikan bangsa ini terlena serta membuat nilai- nilai Pancasila pada warga memudar, serta bisa bawa perihal yang kurang baik untuk negeri ialah terbentuknya kemerosotan generasi muda di negeri indonesia ini. Tidak hanya itu pula yang terserang akibatnya ialah budaya tradisional Indonesia yang turut terbawa- bawa oleh trend globalisasi yang akibatnya menimpa pertumbuhan budaya Indonesia, Pesatnya pertumbuhan globalisasi dalam data serta telekomunikasi menimbulkan kecenderungan menyusutnya aspek dalam berbudaya pada warga. Lemahnya kemauan warga dalam upaya buat melestarikan budaya pada negeri sendiri. pada Budaya Indonesia yang mempunyai karakteristik khas semacam ramah, gotong royong, silih menolong serta santun sudah sedikit pudar oleh terdapatnya budaya asing dari style berpakaian anak muda Indonesia yang sepanjang ini senantiasa mengikuti tata krama menjadi hadapi pergantian 
bersamaan pertumbuhan era. Semacam di kota besar, anak muda wanita lebih cenderung menggunakan baju sedikit serta ketat buat memamerkan bagian badan tertentu. Budaya berpakaian sedikit ini dari film atau majalah asing yang dijadikan sinetron oleh Indonesia [13].

Kedatangan era society 5.0 pastinya bawa pengaruh pada anak muda, baik itu positif serta pula pengaruh negatif. Pengaruh- pengaruh tersebut tidak secara langsung mempengaruhi terhadap nasionalisme. Tetapi secara totalitas bisa memunculkan rasa nasionalisme terhadap bangsa jadi menurun ataupun apalagi lenyap, Terdapatnya globalisasi menimbulkan perpindahan nilai serta anak muda yang semula irasional jadi, Globalisasi sanggup meyakinkan Anak muda Indonesia kalau liberalisme bisa bawa kemajuan serta kemakmuran, Anak muda kurang ingat hendak bukti diri diri selaku bangsa Indonesia sebab style hidupnya cenderung meniru budaya barat; perilaku individualistik yang memunculkan ketidakpedulian antarperilaku sesama masyarakat; dan kesenjangan social [14]. Arus globalisasi tidak mungkin dapat dihentikan. Seiring berjalannya globalisasi tidak lepas dari perkembangan ilmu pengetahuan dan teknologi yang menjadi penyebabnya penyebabnya. Dampaknya juga tidak bisa dihindari. Bagi masyarakat, bangsa dan Negara Indonesi, globalisasi memiliki dampak positif dan negative. Pembudayaan nilai-nilai luhur pada Pancasila perlu kita upayakan. Diharapkan dapat penghayatan dan pengalaman nilainilai luhur pada Pancasila di berbagai bidang kehidupan bagi seluruh masyarakat Indonesia [15].

\section{PENUTUP}

\section{Kesimpulan}

Bersumber pada hasil studi yang telah kami lakukan dapat disimpulkan jika ada 55, 6\% anak muda yang sangat setuju, 40,7\% Setuju, dan sisanya cukup setuju apabila Pancasila itu berarti diterapkan dalam kehidupan masing- masing hari dengan berbagai alibi yang disebutkan. Salah satunya ialah karena Pancasila yakni pedoman yang baik dan berisi nilai nilai kehidupan, Pada masa society 5. 0 semacam dikala ini ini nilai nilai Pancasila sangat tidak kerap diterapkan dan ini diakui oleh $37 \%$ responden kami apabila mereka setuju, 40 , $7 \%$ cukup setuju, $11,1 \%$ Tidak setuju dan $7,4 \%$ sangat tidak setuju. Buat hadapi masa society 5. 0 anak muda perlu adanya penanaman Pancasila dalam dirinya sejak dini Mengenai ini disetujui oleh responden dengan $66,7 \%$ sangat setuju dan $29,6 \%$ yang lain setuju. Responden pula mengidentifikasi nilai nilai yang tercantum dalam Pancasila dan mengidentifikasi makna nilai- nilai tersebut, namun masih banyak yang belum menerapkannya dengan baik dan jadi Kerutinan dalam kehidupan masing- masing hari. Mengenai ini dibuktikan dengan terdapat $22,2 \%$ yang sangat setuju, $66,7 \%$ setuju, dan 11 , $1 \%$ cukup setuju.

Bersumber pada kuesioner yang telah kami bagikan kepada sebagian responden dapat disimpulkan jika Pancasila sangat pengaruhi dalam membenarkan masa depan di masa society ini dan perlu diketahui pula apabila penanaman nilai Pancasila itu sangat perlu ditanamkan sejak dini, masih banyak pula anak muda yang hanya mengidentifikasi pelafalannya saja tanpa tahu makna yang tercantum dan tata cara penerapannya.

\section{Saran}

Dalam menerapkan nilai-nilai pancasila demi terwujudnya remaja yang berkarakter perlu adanya saran yang baik untuk mengurangi hambatan atau tantangan yang dihadapi [6]. 
Anjuran yang dapat diberikan ialah:

1. Dari peran orang tua, sebaiknya bisa memberikan contoh kepada anak karena nanti hendak jadi generasi penerus buat bangsa ini. Apabila orang tua itu memberikan contoh kurang baik kepada anak yakni semacam tidak menghargai produk dalam negeri contohnya masih terus membeli dan mengenakan produk dari luar negeri, sampai anakpun hendak menjajaki contoh dari orang tuanya karena orang tua memiliki peran jadi pendidik dini dikala saat sebelum anak terjun keluar ke zona yang lebih luas lagi.

2. Sarana dari sesuatu pendidikan dan dari pembelajaran pendidikan pancasila di sekolah yang baru hanya formalitas untuk memusatkan nilai-nilai Pancasila. Oleh karena itu, sangat perlu pengaktualisasian dalam nilai- nilai pancasila didalam kehidupan bersama dan kehidupan masing- masing hari. Sepatutnya diadakan upaya buat menghayati dan menerapkan nilai- nilai Pancasila dalam kehidupan bersama buat para anak muda.

3. Buat pemerintah yang ada di indonesia, hendaknya berupaya semaksimal dapat jadi buat memberikan penjelasan tentang Pancasila buat para anak muda misalnya dengan mengadakan sosialisasi tentang Pancasila buat menarik atensi para anak muda buat menjajaki dan menekuni lebih dalam tentang Pancasila (Marlina, 2016).

\section{UCAPAN TERIMA KASIH}

Penulis ingin mengucapkan banyak terima kasih kepada Tuhan Yang Maha Esa atas limpahan rahmat serta hidayahnya dan terima kasih kepada kepada masing-masing penulis karena telah berusaha semaksimal mungkin sehingga dapat menyelesaikan artikel ilmiah ini dengan baik.

\section{DAFTAR PUSTAKA}

[1] Wulandari, A. D., \& Dewi, D. A. (2021). Urgensi Membumikan Pancasila Bagi Karakter Penerus Bangsa di Era Globalisasi. Jurnal Pendidikan Tambusai, 5(2018), 926-930. https://www.jptam.org/index.php/jptam/article/view/1054

[2] Atmawarni, A., \& Kesuma, S. (2021). PENERAPAN NILAI-NILAI PANCASILA TERHADAP PEMBINAAN MORAL REMAJA. Genta Mulia: Jurnal IImiah Pendidikan, 12(1).

[3] Zainab, M. S., \& Dewi, D. A. (2021). Peran Pancasila dalam Menumbuhkan Nasionalisme bagi Warga Negara Indonesia. Rhizome :Jurnal Kajian IImu IImu Humaniora, 1(3), 1-7.

[4] Putri, A. M., \& Andrian, A. L. F. (2020). Pengaruh Media Sosial terhadap Nilai-Nilai yang Terkandung dalam Pancasila pada Generasi Z. Syntax Idea, 2(12).

[5] Marlina, E. (2016). Internalisasi Nilai-Nilai Pancasila dan Rasa Cinta Tanah Air pada Remaja di Perbatasan Indonesia-Malaysia. Psikoborneo, 4(4), 564.

[6] Damanhuri, D., Bahrudin, F. A., Legiani, W. H., \& Rahman, I. N. (2016). Implementasi Nilai-Nilai Pancasila Sebagai Upaya Pembangunan Karakter Bangsa. Untirta Civic Education Journal, 1(2).

[7] Nugroho, S. S., Anam, M. C., Pudjiono, M. J., Rahardjo, M., \& Sukarjono, B. (2020). Implementasi Konsep Pendidikan Karakter Ki Hajar Dewantara Berbasis Nilai-Nilai Pancasila Bagi Mahasiswa Generasi Mileneal. YUSTISIA MERDEKA: Jurnal Ilmiah Hukum, 6(2), 89-94. https://doi.org/10.33319/yume.v6i2.61

[8] Meinarno, E. A., \& Mashoedi, S. F. (2016). Pembuktian Kekuatan Hubungan Antara Nilai-Nilai Pancasila Dengan Kewarganegaraan. Jurnal Ilmiah Pendidikan Pancasila Dan Kewarganegaraan, 1(1), 12-22. https://doi.org/10.17977/um019v1i12016p012

[9] An'Umillah, A. N., Supriyono, S., \& Nugraha, D. M. (2021). Pentingnya Peran Nilai-Nilai Pancasila Terhadap Karakter Remaja Pada Era Globalisasi Dan Distrupsi. Harmony, 6(1), 35-41.

[10] Pitoewas, B. (2018). Pengaruh lingkungan sosial dan sikap remaja terhadap perubahan tata nilai. JPK (Jurnal Pancasila dan Kewarganegaraan), 3(1), 8-18. http://journal.umpo.ac.id/index.php/JPK/index

[11] çimen, sabri. (2021). AKTUALISASI PANCASILA SEBAGAI REFLEKSI MEMBANGUN KARAKTER 
ANAK: BENTUK UPAYA PREVENTIF PERLINDUNGAN ANAK DI LINGKUNGAN DESA (STUDI DESA KRAGILAN, KECAMATAN MOJOLABAN, KABUPATEN SUKOHARJO). 01(02), 6.

[12] Siti, S., \& Anggraeni, D. (2021). Implementasi Nilai Pancasila Melalui Pendidikan Bagi Generasi Milenial. Jurnal Penelitian Ilmu Sosial, 1(11), 1-6. https://journal.actual-insight.com/index.php/konstruksisosial/article/view/240

[13] Oktari, D., \& Dewi, D. A. (2021). Pemicu Lunturnya Nilai Pancasila Pada Generasi Milenial. JURNAL PEKAN : Jurnal Pendidikan Kewarganegaraan, 6(1), 93-103. https://doi.org/10.31932/jpk.v6i1.1170

[14] Hermawan, D. (2019). DAMPAK GLOBALISASI TERHADAP MORALITAS REMAJA (Studi SMK Swasta Putra Bunda Tanjung Pura) Tahun Pelajaran 2018/2019. Jurnal Serunai Pancasila Dan Kewarganegaraan, 8(1), 88-93.

[15] Asmaroini, A. P. (2017). Menjaga eksistensi Pancasila dan penerapannya bagi masyarakat di era globalisasi. JPK: Jurnal Pancasila dan Kewarganegaraan, 1(2), 50-64. 